(c) American Dairy Science Association, 2004.

\title{
Individual Variation in the Milk Yield Response to Bovine Somatotropin in Dairy Cows
}

\author{
M. T. Rose, ${ }^{\star}$ T. E. C. Weekes, $†$ and P. Rowlinson \\ School of Agriculture, Food and Rural Development, \\ University of Newcastle upon Tyne, NE1 7RU, United Kingdom
}

\begin{abstract}
The objective was to relate the short-term milk yield response (MYR) following use of exogenous bovine somatotropin (bST) to changes in plasma concentrations of metabolites and hormones. Twenty-four Holstein cows ( $52 \pm 4.1 \mathrm{~d}$ postpartum) received daily subcutaneous injections of saline for 1 wk followed by subcutaneous injections of $33 \mathrm{mg} / \mathrm{d}$ of bST for $2 \mathrm{wk}$ (Trial 1). The difference in milk yield between wk 1 and 3 for each cow was used to determine the 5 cows with the highest (HR) and 5 with the lowest responses (LR) to bST. These 10 cows were then used in 3 further trials of the same design (Trials 2, 3, and 4, conducted at 122, 181, and $237 \pm 7.6 \mathrm{~d}$ postpartum, respectively). Blood samples were taken $2 \mathrm{~h}$ after the administration of bST on $\mathrm{d} 1$, $3,5,15,17$, and 19 of each trial. The HR group had consistently greater MYR to bST than the LR group throughout their lactation. The LR group had a higher milk yield and lower plasma insulin like growth factorI (IGF-I) concentrations during the saline treatment in all trials. The increase in plasma somatotropin concentrations following injections of bST was greater for the LR group, whereas the difference in plasma IGF-I level between wk 1 and 3 was greater for the HR group. The HR group had lower levels of 3-hydroxy-butyrate and nonesterified fatty acids before bST treatment. Low short-term response to bST was associated with plasma concentrations of hormones and metabolites that indicate negative energy balance, although other factors may be involved.
\end{abstract}

(Key words: bovine somatotropin, growth hormone, insulin-like growth factor-I))

Abbreviation key: HR = high response, $\mathbf{L R}=$ low response, $\mathbf{M Y R}=$ milk yield response .

Received December 11, 2003.

Accepted March 2, 2004.

Corresponding author: M. T. Rose; e-mail: mir@aber.ac.uk.

*Present address: Institute of Rural Sciences, University of Wales, Aberystwyth, SY23 3AL, UK.

$\dagger$ Deceased.

\section{INTRODUCTION}

Substantial increases in milk production have been reported when dairy cows have received injections of recombinant bST; the average milk yield response (MYR) to bST is generally 2 to $5 \mathrm{~kg} / \mathrm{d}$ greater than that of excipient-injected control cows (Chalupa et al., 1987; Bauman, 1992). The first study to report the effects of long-term treatment of dairy cows with bST noted that at the highest dose used $(40 \mathrm{mg} / \mathrm{d})$, the milk yield of the treated animals was more than $11 \mathrm{~kg} / \mathrm{d}$ greater than that of control animals (Bauman et al., 1985). Even at a lower dose $(25 \mathrm{mg} / \mathrm{d})$, the MYR of cows in that study was more than $10 \mathrm{~kg} / \mathrm{d}$. These levels of response have rarely been repeated since. Other studies have reported somewhat disappointing MYR to the hormone. In the study of Lormore et al. (1990), again administering $25 \mathrm{mg} / \mathrm{d}$ of the hormone, no significant effect on the milk yield of the cows was observed. The MYR to slow release formulations of somatotropin have also been variable. The studies of Hof et al. (1991) and Marty and Block (1992) both used $320 \mathrm{mg}$ of bST injected at 14-d intervals, and both noted insubstantial increases in milk yield following treatment. Whereas these particular studies are clearly examples of the extremes of the potential MYR, it is clear that considerable variability in response has occurred among trials. In contrast to the number of studies reporting average results for whole herds, relatively little information has been published concerning variation in the MYR among individual cows within a herd. The notion of individual variation in MYR to bST is contentious, however; for example, Bauman (1992) suggested that the variation in milk yields of bSTtreated cows was similar to that of untreated cows.

In addition to dose of the product, a number of factors are known to affect MYR. Treatment that begins in early lactation generally results in poor MYR (Marty and Block, 1992). It is widely accepted that the quality of the cows' management (nutrition, environment, health, milking practice, etc.) is also important for determining its extent (Bauman, 1992; Newbold et al., 1997). A positive correlation of 0.58 has been observed between pretreatment herd milk yield and the MYR 
to bST (Bauman, 1992). Pretreatment milk yield was used by the latter author as an indicator of the general quality of management. This example notwithstanding, a number of authors have noted a negative correlation within herds between the milk yield of untreated cows and the MYR. That is, cows with larger milk yields without treatment tend to have lower MYR (Leitch et al., 1990; Gibson et al., 1992). One trial with apparently good nutritional management noted a very poor MYR (Hof et al., 1991)

The aim of the present study was to investigate the extent of the individual variation in the MYR in Holstein dairy cows managed under the same circumstances and given the same dose of bST. Cows were identified as high and low responding in early lactation and were used in a series of further experiments. Plasma levels of hormones and metabolites were measured and the association between these and the MYR of the high- and low-responding groups were noted.

\section{MATERIALS AND METHODS}

Twenty-four fall-calving, multiparous, Holstein cows from the Cockle Park herd of the University of Newcastle-upon-Tyne were used in a 3-wk experiment (Trial 1). The cows averaged $52 \pm 4.1 \mathrm{~d}$ postpartum at the start of Trial 1. During wk 1, each cow received a daily injection of sterile PBS (saline treatment) at 0630 $\mathrm{h}$, following the morning milking. During wk 2 and 3, the cows received daily injections of $33 \mathrm{mg} / \mathrm{d}$ of bST (American Cyanamid Co., Princeton, NJ) dissolved in PBS, injected at the same time each day. All injections were subcutaneous and administered in the flank area, forward and above the mammary gland.

Cows were milked twice daily at approximately 0600 and $1530 \mathrm{~h}$. Milk yields of each cow were recorded at each milking. Samples of milk from 2 morning and 2 afternoon milkings per week were retained for determination of concentrations of fat, protein, and lactose (analyzed by National Milk Records, Harrogate, North Yorkshire, UK). The MYR of each cow to bST was defined as the difference in milk yield $(\mathrm{kg} / \mathrm{d})$ between the average of wk 1 and the average of wk 3, Trial 1 . The 5 cows with the greatest MYR to bST (HR) and the 5 cows with the lowest MYR to bST (LR) were used in a series of 3 further experiments (Trials 2, 3, and 4 , respectively). These further trials were conducted when these cows were $122 \pm 7.6,181 \pm 7.6$, and $237 \pm 7.6 \mathrm{~d}$ postpartum, respectively. Trials 2,3 , and 4 were designed exactly as Trial 1 .

During Trials 1 and 2, cows were loose housed in freestalls with free access to a feeding passage. During Trials 3 and 4, cows were at pasture between milkings both day and night. During Trials 1 and 2, cows had ad libitum access to grass silage (average analysis: $283 \mathrm{~g}$ of DM $/ \mathrm{kg} ; 129 \mathrm{~g}$ of CP/kg of DM; $12.1 \mathrm{MJ}$ of ME/ $\mathrm{kg}$ of DM). In addition, $1.9 \mathrm{~kg} / \mathrm{cow}$ (DM) of rolled barley was fed to the cows as a group on top of the silage once per day. In all 4 trials, the cows were fed a commercial compound concentrate (910 $\mathrm{g}$ of DM/kg; $210 \mathrm{~g}$ of $\mathrm{CP} /$ $\mathrm{kg}$; $13.6 \mathrm{MJ}$ of ME/kg). The amount of concentrate fed was according to usual farm practice; the concentrate was split into 2 parts and fed twice per day in the milking parlor. Concentrate allocation was determined for each cow 2 wk before each trail, and this level of feeding was maintained until the end of that particular trial. Cows yielding 15 to 20,20 to 25,25 to 30 , and 30 to $35 \mathrm{~kg}$ of milk/d were offered concentrate at $2.7,4.6,6.4$, and $8.2 \mathrm{~kg}$ of $\mathrm{DM} / \mathrm{d}$, respectively, throughout each trial. However, those amounts were adjusted if a cow was considered under- or overconditioned. Amounts of concentrate offered were not significantly different between the HR and LR groups: cows in the HR group in Trials 1, 2, 3, and 4 were offered (mean \pm SE) $7.8 \pm 0.36,7.1 \pm 0.44,1.6 \pm 0.66$, and 0.5 $\pm 0.5 \mathrm{~kg} \mathrm{DM}$ of concentrate per day, respectively; and cows in the LR group were offered $8.2 \pm 0.0,7.5 \pm 0.44$, $1.6 \pm 0.66$, and $0.5 \pm 0.5 \mathrm{~kg}$ of $\mathrm{DM} / \mathrm{d}$, respectively. The same individual recorded live weights and BCS (East of Scotland College of Agriculture, 1976) of each cow twice weekly in each of the 4 trials.

Peripheral venous blood samples were taken by venipuncture at $0830 \mathrm{~h}$ on d $1,3,5,15,17$, and 19 of all 4 trials, $2 \mathrm{~h}$ after the injection of bST. In Trial 2, cows also had blood sampled at 0000, 0400, 1200, 1630, 2000 , and $2400 \mathrm{~h}$ on $\mathrm{d} 5$ and 19. Each time, the area of skin was disinfected, the sample was obtained from the coccygeal vein using a $10-\mathrm{mL}$ heparinized evacuated test tube and then placed on ice. Plasma was harvested by centrifugation and stored at $-20^{\circ} \mathrm{C}$ until analysis. Plasma samples were analyzed for somatotropin (Johke, 1978), insulin (Fuller et al., 1977), and IGF-I (commercial kit, Nichols Institute Diagnostics, San Clemente, CA) by radioimmunoassay. Binding proteins for IGF-I were removed using the acid ethanol extraction procedure (Echternkamp et al., 1990). Inter- and intraassay coefficients of variation were 6.7 and $5.8 \%$, respectively, for the somatotropin assay, 7.3 and $9.5 \%$ for the insulin assay, and 11.3 and $12.4 \%$ for the IGF-I assay. Using commercially available kits, plasma was also analyzed for glucose (Hoffmann-La Roche Diagnostics, Basel, Switzerland), 3-hydroxybutyrate (Sigma-Aldrich, Poole, UK), and NEFA (Wako Chemicals, Osaka, Japan) using an automatic analyzer. In all cases, the inter-and intraassay coefficients of variation were below $3 \%$.

For the statistical analyses, the average value obtained during wk 1 for each cow of each trial and the 
Table 1. Response to bST (difference between the averages of wk 1 and 3 of each trial) for the high and low responding groups of cows in 4 trials conducted at different stages of lactation ${ }^{1}$.

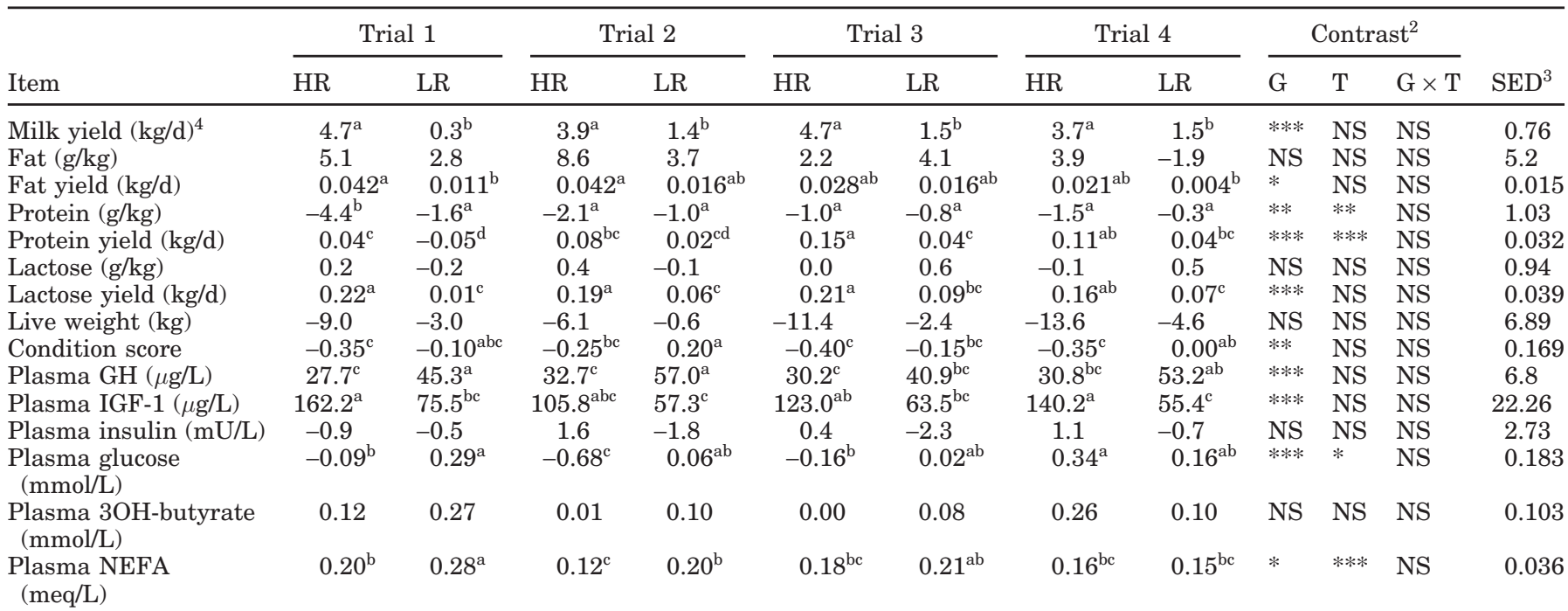

${ }^{1}$ Trials $1,2,3$, and 4 began when the cows were on average $52 \pm 4.1,122 \pm 7.6,181 \pm 7.6$, and $237 \pm 7.6 \mathrm{~d}$ postpartum, respectively. HR $=$ High milk yield response and LR $=$ low response to BST, as determined during Trial 1.

${ }^{2}$ Significance of difference between response groups $(\mathrm{G})$, trials $(\mathrm{T})$, and the interaction between response group and trial $(\mathrm{G} \times \mathrm{T})$. NS: not significant $(P>0.05) ; * P<0.05 ; * * P<0.01 ; * * * P<0.001$.

${ }^{3}$ Standard error of the difference.

${ }^{4}$ Means with different superscripts within rows are significantly different at $P<0.05$.

difference between wk 1 and 3 of each trial (defined as the response to bST) were determined. Because records from different trials within cows were correlated, the data were analyzed using the repeated-measures ANOVA Correlation Models by REML procedure of the Genstat 5 for Windows statistical software (release 6.1, VSN Int., Ltd., Oxford, UK). The random term was "cow," and the fixed terms were "response group" and "trial." The Schwarz's-Bayesian information criterion was used to identify a variance-covariance model that adequately described the data. Either the compound symmetry model or the first-order autoregressive model best described the variance-covariance structures in all cases. The least significant difference between individual means was determined using the average standard error of the difference; the residual degrees of freedom appropriate to the variance-covariance structure were used. Rather than having a combined ANOVA incorporating week, trial number, and response group, the main statistical analysis was performed in two parts: on the average values obtained in wk 1 (saline treatment weeks) of each trial, and then on the response to bST (difference between wk 1 and 3). The data were analyzed in this way because of inconsistent lengths of time among repeated measures ( 2 wk separated wk 1 and 3 of each trial, whereas trials were separated by 8 to $10 \mathrm{wk})$. This increased the reliability of the fit of the variance-covariance models to the data. Other statistical comparisons were done using Student's paired $t$-test as indicated in the results.

\section{RESULTS}

The response to bST (difference between wk 1and 3) for each variable measured in each trial for the HR and LR groups is given in Table 1 . The average value observed in wk 1 (before bST treatment) in each trial for the HR and LR groups of cows is given in Table 2.

The average milk yield of the 24 cows initially used in Trial 1, in the first week (saline treatment), was $29.4 \pm 1.22 \mathrm{~kg} / \mathrm{d}$. This increased to $31.5 \pm 1.85 \mathrm{~kg} / \mathrm{d}$ in the second week of bST treatment $(P<0.001$, Student's paired $t$-test). This represents an additional $2.1 \mathrm{~kg} / \mathrm{d}$. The HR and LR groups (each of 5 cows) were selected from these 24 cows based on their MYR to bST in the first trial. The differential MYR of the 2 groups was maintained for the remainder of the Trials 2,3 , and 4 (Table 1). There was, however, a nonsignificant tendency for the MYR of the groups to converge slightly as lactation progressed. The LR group had higher milk yields in the pre-bST treatment week throughout all trials (Table 2).

There was no significant effect of group on the increase in milk fat content following bST treatment. Equally, there was no significant effect of group on the 
Table 2. Average values in wk 1 (prior to bST treatment) for the high and low responding groups of cows in 4 trials conducted at different stages of lactation. ${ }^{1}$

\begin{tabular}{|c|c|c|c|c|c|c|c|c|c|c|c|c|}
\hline \multirow[b]{2}{*}{ Item } & \multicolumn{2}{|c|}{ Trial 1} & \multicolumn{2}{|c|}{ Trial 2} & \multicolumn{2}{|c|}{ Trial 3} & \multicolumn{2}{|c|}{ Trial 4} & \multicolumn{3}{|c|}{ Contrast $^{2}$} & \multirow[b]{2}{*}{$\mathrm{SED}^{3}$} \\
\hline & $\mathrm{HR}$ & LR & HR & LR & HR & LR & HR & LR & $\mathrm{G}$ & $\mathrm{T}$ & $\mathrm{G} \times \mathrm{T}$ & \\
\hline Milk yield $(\mathrm{kg} / \mathrm{d})^{4}$ & $24.6^{\mathrm{bc}}$ & $33.0^{\mathrm{a}}$ & $21.8^{\mathrm{bcd}}$ & $26.8^{\mathrm{b}}$ & $20.6^{\mathrm{bcd}}$ & $24.9^{\mathrm{b}}$ & $13.8^{\mathrm{e}}$ & $19.0^{\mathrm{de}}$ & $*$ & $* * *$ & NS & 2.66 \\
\hline Fat $(\mathrm{g} / \mathrm{kg})$ & 44.5 & 40.6 & 40.8 & 39.6 & 40.6 & 37.9 & 41.1 & 44.1 & NS & NS & NS & 4.32 \\
\hline Fat yield $(\mathrm{kg} / \mathrm{d})$ & $1.09^{\mathrm{ab}}$ & $1.33^{\mathrm{a}}$ & $0.89^{\mathrm{bc}}$ & $1.06^{\mathrm{b}}$ & $0.83^{\mathrm{c}}$ & $0.94^{\mathrm{bc}}$ & $0.57^{\mathrm{d}}$ & $0.84^{\mathrm{c}}$ & $*$ & $* * *$ & NS & 0.122 \\
\hline Protein (g/kg) & $34.8^{\mathrm{ab}}$ & $30.6^{\mathrm{c}}$ & $32.8^{\mathrm{bc}}$ & $30.2^{\mathrm{c}}$ & $35.9^{\mathrm{a}}$ & $35.1^{\mathrm{ab}}$ & $35.7^{\mathrm{a}}$ & $33.7^{\mathrm{ab}}$ & * & $* * *$ & NS & 1.17 \\
\hline Protein yield $(\mathrm{kg} / \mathrm{d})$ & $0.86^{\mathrm{ab}}$ & $0.98^{\mathrm{a}}$ & $0.71^{\mathrm{b}}$ & $0.78^{\mathrm{ab}}$ & $0.73^{\mathrm{b}}$ & $0.87^{\mathrm{ab}}$ & $0.49^{\mathrm{c}}$ & $0.64^{\mathrm{c}}$ & NS & $* * *$ & NS & 0.097 \\
\hline Lactose $(\mathrm{g} / \mathrm{kg})$ & 45.5 & 46.4 & 45.6 & 47.1 & 44.3 & 45.7 & 44.4 & 44.9 & NS & NS & NS & 1.29 \\
\hline Lactose yield $(\mathrm{kg} / \mathrm{d})$ & $1.12^{\mathrm{bc}}$ & $1.53^{\mathrm{a}}$ & $1.00^{\mathrm{bcd}}$ & $1.26^{\mathrm{ab}}$ & $0.91^{\mathrm{c}}$ & $1.14^{\mathrm{bc}}$ & $0.61^{\mathrm{e}}$ & $0.85^{\mathrm{de}}$ & * & $* * *$ & NS & 0.136 \\
\hline Live weight (kg) & $575^{\mathrm{b}}$ & $587^{\mathrm{ab}}$ & $579^{\mathrm{b}}$ & $589^{a b}$ & $589^{a b}$ & $596^{\mathrm{ab}}$ & $597^{\mathrm{ab}}$ & $602^{a}$ & NS & $* * *$ & NS & 10.1 \\
\hline Condition score & $3.0^{\mathrm{ab}}$ & $2.1^{\mathrm{d}}$ & $2.8^{\mathrm{b}}$ & $2.1^{\mathrm{d}}$ & $3.3^{\mathrm{a}}$ & $2.5^{\mathrm{c}}$ & $3.3^{\mathrm{a}}$ & $2.7^{\mathrm{bc}}$ & $* *$ & $* * *$ & NS & 0.11 \\
\hline Plasma GH $(\mu \mathrm{g} / \mathrm{L})$ & $5.90^{\mathrm{a}}$ & $4.68^{\mathrm{a}}$ & $6.32^{\mathrm{a}}$ & $4.42^{\mathrm{a}}$ & $4.28^{\mathrm{ab}}$ & $4.74^{\mathrm{a}}$ & $1.05^{\mathrm{b}}$ & $1.19^{\mathrm{b}}$ & NS & $* *$ & NS & 1.49 \\
\hline Plasma IGF-1 $(\mu \mathrm{g} / \mathrm{L})$ & $91.6^{\mathrm{a}}$ & $62.3^{\mathrm{ab}}$ & $88.8^{\mathrm{ab}}$ & $68.5^{\mathrm{ab}}$ & $90.2^{\mathrm{a}}$ & $62.7^{\mathrm{ab}}$ & $89.9^{\mathrm{a}}$ & $58.8^{\mathrm{b}}$ & $* *$ & NS & NS & 15.06 \\
\hline Plasma insulin $(\mu / \mathrm{L})$ & $13.2^{\mathrm{bc}}$ & $4.8^{\mathrm{d}}$ & $16.0^{\mathrm{ab}}$ & $11.2^{\mathrm{c}}$ & $16.2^{\mathrm{ab}}$ & $10.6^{\mathrm{c}}$ & $19.3^{\mathrm{a}}$ & $10.2^{\mathrm{c}}$ & $* * *$ & $* * *$ & * & 1.53 \\
\hline $\begin{array}{l}\text { Plasma glucose } \\
(\mathrm{mmol} / \mathrm{L})\end{array}$ & $3.66^{\mathrm{cd}}$ & $3.48^{\mathrm{d}}$ & $3.70^{\mathrm{cd}}$ & $3.44^{\mathrm{d}}$ & $3.91^{\mathrm{bc}}$ & $3.73^{\text {cd }}$ & $4.52^{\mathrm{a}}$ & $4.18^{\mathrm{b}}$ & $* *$ & $* * *$ & NS & 0.148 \\
\hline $\begin{array}{l}\text { Plasma 3OH-butyrate } \\
(\mathrm{mmol} / \mathrm{L})\end{array}$ & $0.473^{\mathrm{e}}$ & $0.787^{\mathrm{ab}}$ & $0.588^{\mathrm{de}}$ & $0.762^{\mathrm{abc}}$ & $0.711^{\mathrm{cd}}$ & $0.863^{\mathrm{a}}$ & $0.424^{\mathrm{e}}$ & $0.608^{\mathrm{de}}$ & $* * *$ & $* * *$ & NS & 0.0616 \\
\hline $\begin{array}{l}\text { Plasma NEFA } \\
(\mathrm{mmol} / \mathrm{L})\end{array}$ & $0.104^{\mathrm{c}}$ & $0.148^{\mathrm{ab}}$ & $0.136^{\mathrm{abc}}$ & $0.172^{\mathrm{a}}$ & $0.130^{\mathrm{abc}}$ & $0.164^{\mathrm{a}}$ & $0.113^{\mathrm{bc}}$ & $0.148^{\mathrm{a}}$ & $* * *$ & NS & NS & 0.0185 \\
\hline
\end{tabular}

${ }^{1}$ Trials $1,2,3$, and 4 began when the cows were on average $52 \pm 4.1,122 \pm 7.6,181 \pm 7.6$, and $237 \pm 7.6 \mathrm{~d}$ postpartum, respectively. HR $=$ high milk yield response and $\mathrm{LR}=$ low response to bST, as determined during Trial 1.

${ }^{2}$ Significance of difference between response groups $(\mathrm{G})$, trials $(\mathrm{T})$, and the interaction between response group and trial $(\mathrm{G} \times \mathrm{T}) . \mathrm{NS}:$ not significant $(P>0.05) ;{ }^{*} P<0.05$; $* * P<0.01 ; * * * P<0.001$.

${ }^{3}$ Standard error of the difference.

${ }^{4}$ Means with different superscripts within rows are significantly different at $P<0.05$. 


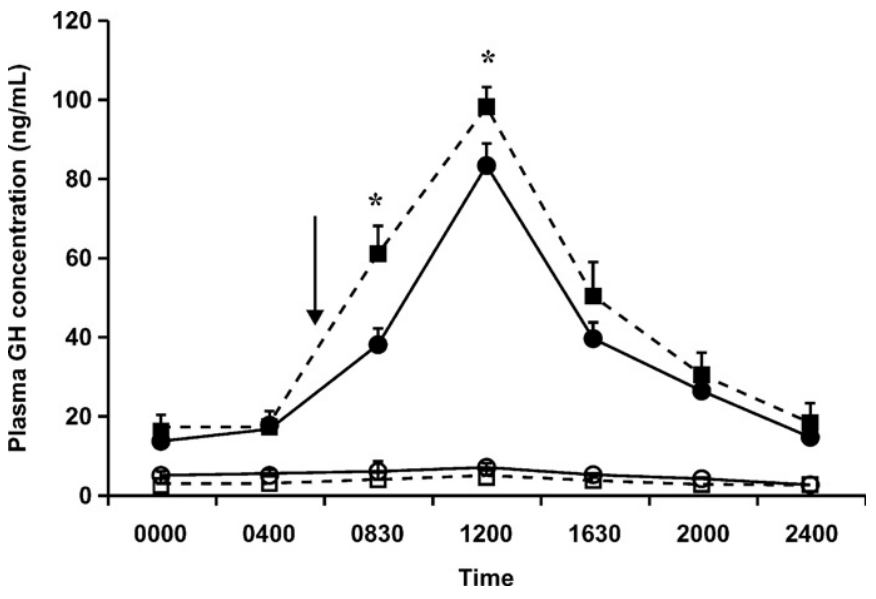

Figure 1. Profile of plasma somatotropin over $24 \mathrm{~h}$ in dairy cows receiving saline $(\bigcirc, \square)$ for 1 wk followed by bST treatment $(\bullet, \square)$ during wk 2. Dairy cows were identified as having a high milk yield response to bST $(\square, \square)$ or identified as having a low milk yield response to bST $(O, \square)$ in early lactation. Injections of bST were administered daily at $0630 \mathrm{~h}$ (indicated by arrow). Plasma somatotropin concentrations were significantly different between the response groups during bST treatment at 0830 and $1200 \mathrm{~h}$ (indicated by asterisks).

milk fat content before bST treatment. The reduction in the milk concentration of protein was significantly greater for the HR group than it was for the LR group across all trials. The HR group had a significantly greater milk protein concentration before bST treatment. The concentration of lactose in the milk before bST treatment, as well as the lactose concentration response to bST, was not different between the groups of cows.

The loss in live weight with the bST treatment was not significantly different between the HR and LR groups across all trials. Further, the live weight of the cows was not significantly different between the groups before bST treatment. The loss in BCS was, however, significantly greater for the HR group following bST treatment than it was for the LR group. Before bST treatment, the HR group had significantly greater condition scores than the LR group.

The extent of the increase in circulating somatotropin concentrations following bST treatment was significantly greater for the LR group relative to that of the HR group. There was no significant difference between the groups with regard to the plasma concentration of somatotropin before the bST treatment. In Trial 2, the plasma concentrations of somatotropin were significantly greater for the LR cows at 0830 and $1200 \mathrm{~h}$ (Student's paired $t$-test) on d 19, relative to the respective values for the HR group (Figure 1). None of the other plasma hormones or metabolites measured had a consistent profile over $24 \mathrm{~h}$ (results not shown). The increase in the plasma concentration of IGF-I fol-

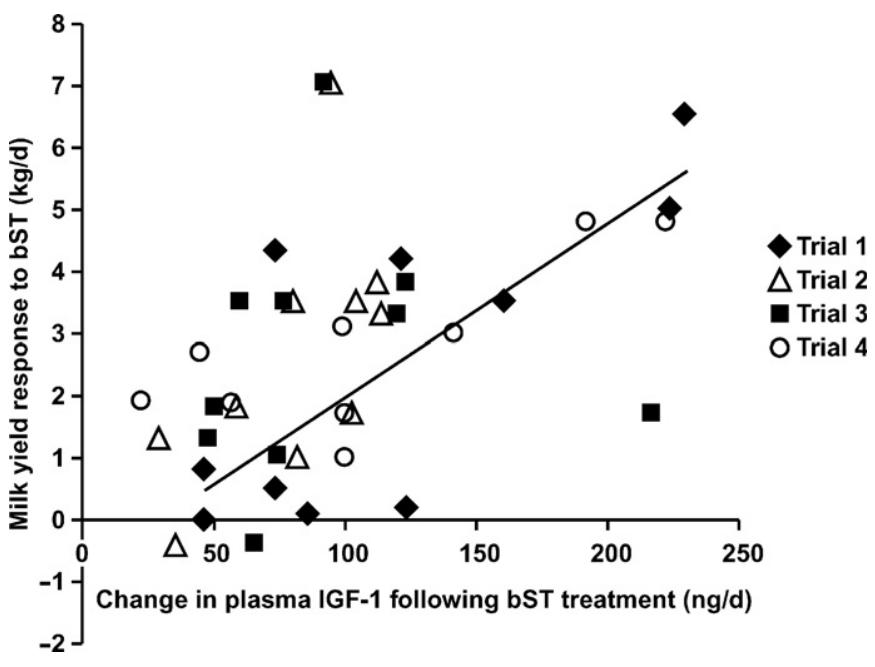

Figure 2. Correlation of the increase in plasma IGF-I following bST treatment against the milk yield response to bST for Trials 1 , 2,3 , and 4 combined. The equation of the best-fit line is $\mathrm{y}=0.0278 \mathrm{x}$ $-0.7976, R^{2}=0.589$

lowing bST treatment was significantly greater for the HR cows than it was for the LR cows. This relationship is also illustrated by the significant $(P<0.01)$ correlation between the increase in plasma IGF-I concentrations following bST treatment and the MYR (Figure 2). The HR cows also had significantly greater plasma concentrations of IGF-I before the bST treatment.

The change in the plasma insulin levels between wk 1 and 3 of the trials was not significantly different between the HR and LR groups over all of the trials. The HR cows had significantly greater insulin levels before the bST treatment than the LR cows, though there was an interaction with stage of lactation such that this effect was more pronounced in Trial 1 . The increase in plasma concentrations of glucose in the LR group following bST treatment was significantly different from that of the HR group, where plasma glucose concentrations tended to decrease. Before bST treatment, plasma concentrations of glucose were significantly greater in the HR group relative to the LR cows. There was no significant difference in the response of the HR and LR groups with regard to the change in the plasma concentration of 3-hydroxy-butyrate with bST treatment. The HR group of cows had significantly lower levels of 3-hydroxy-butyrate before bST treatment. The increase in the plasma concentration of NEFA following bST treatment was significantly greater for the LR group of cows relative to that of the HR group. Before the bST treatment, the LR cows had significantly greater circulating concentrations of NEFA. 


\section{DISCUSSION}

The $2.1 \mathrm{~kg} / \mathrm{d}$ average MYR to bST (difference in milk yield between wk 1 and 3) for the 24 cows initially used in Trial 1 is at the lower end of the observed range of MYR to bST. Chalupa et al. (1987) noted that the average MYR to long-term treatment with bST ranged between an additional 1.7 and $6.8 \mathrm{~kg}$ of milk/ $\mathrm{d}$ across a number of trials. More than $1 \mathrm{wk}$ may have been required for the MYR to become fully manifest in the present experiment, although it is generally accepted that $1 \mathrm{wk}$ is sufficient (Bauman, 1992).

The HR group (selected from the highest responding cows in Trial 1) maintained a substantial MYR throughout lactation, whereas cows in the LR group were consistently less able to respond. But there was a nonsignificant tendency for the differential MYR between the groups to diminish as lactation progressed. Nevertheless, the implication of the present study is that within the confines of a single lactation, the shortterm response to bST, as determined in early lactation, did reflect the milk yield responses observed later in lactation. The existence of individual variation in response to bST remains controversial. For example, Bauman (1992) stated that all cows in a herd respond to bST to a similar extent. This conclusion was based on the observation that the variation in the milk yield of bST-treated groups is similar to that of untreated groups. Whereas it is accepted that strong conclusions cannot be drawn, as the present experiment was largely based on the milk yields of just 10 cows, there appeared to be a reduced variation in milk yield after bST treatment. That is, the HR group (with the greatest MYR) had the lowest milk yields before treatment (Table 2). Indeed, a number of experiments have demonstrated that, within a herd, the milk yield of cows with higher responses to bST is lower pretreatment than that of lower-responding cows (e.g., Leitch et al., 1990; Gibson et al., 1992). Whether the HR cows of the present experiment would have maintained their responses to bST during prolonged treatment or in further lactations remains to be established.

The indicators are that the LR group of cows in the present experiment was in a deeper and more prolonged negative energy balance relative to the HR group. Before the bST treatment, the LR group of animals had substantially lower milk protein levels, lower BCS, and lower plasma IGF-I, insulin, and glucose levels, but higher 3-hydroxy butyrate and NEFA concentrations. Each of these is associated with a negative energy balance in dairy cows (Reist et al., 2002). Feed intakes were not measured in the present experiment, and therefore energy balances cannot be estimated. However, the results may indicate that individual cows that have lower levels of body energy stores or greater rates of existing energy mobilization before bST treatment may have lower MYR to bST in the short-term. Negative energy balance has been associated with poor MYR to bST (Bauman, 1992, 1999). This notwithstanding, a number of studies have demonstrated that an increased plane of nutrition does not necessarily increase the short-term MYR to bST (Lormore et al., 1990; Vicini et al., 1995).

Although conclusions drawn from single measurements of plasma somatotropin must be treated with caution, the increase in the plasma concentration of somatotropin, $2 \mathrm{~h}$ after injection of bST, relative to untreated levels was substantially greater in the LR group of cows. The results from Trial 2, as well as our unpublished observations, have demonstrated that at this dose of bST, the peak somatotropin concentration occurs approximately $5 \mathrm{~h}$ after its subcutaneous injection. The profile of somatotropin from Trial 2 (Figure 1) appears to be consistently greater in the LR cows for a considerable part of the day. These results suggest that the metabolic clearance rate of somatotropin for the HR group may have been greater than that of the LR group, given that the amount injected was far in excess of the amounts normally secreted by the anterior pituitary gland in dairy cows (and therefore is unlikely to be due to a difference in secretion rate). In growing cattle, hepatic clearance of somatotropin accounts for a substantial fraction of the secretion rate at basal somatotropin concentrations (Lapierre et al., 1999). Furthermore, the clearance of somatotropin by the liver of growing cattle has been shown to be reduced when these animals enter a period of negative energy balance, partially accounting for the increased plasma somatotropin levels noted in this physiological state (Lapierre et al., 1992). This further suggests that the LR group was possibly in a greater and more prolonged negative energy balance in the present experiment. It is thought that the number of hepatic bST receptors may regulate the differential MYR to bST. Hard et al. (1992) measured more ${ }^{125}$ I-labeled bST binding to hepatic membrane fragments from cows fed diets high in energy and protein, compared with fragments from cows fed diets of lower energy. This is thought to correlate positively with circulating concentrations of IGF-I (Wang et al., 2003).

Plasma IGF-I concentrations increased to a greater extent in the HR group following bST treatment, and in the non-bST-treated state were higher in the HR group than the respective values for the LR group. This suggests that the metabolic clearance rate of IGFI was lower in the HR group of animals, or that the HR group had a greater rate of IGF-I secretion, or both. Higher plasma IGF-I concentrations (of hepatic 
origin) with improved feeding have been shown previously in lactating dairy cows (McGuire et al., 1995) as well as in sheep (Hodgkinson et al., 1991) following bST treatment. In the present experiment, we noted a positive relationship between the MYR and plasma IGF-I responses to bST. Uncoupling of the IGF-I response to bST, as may have occurred in the LR group, has been suggested to protect against an excessive MYR should body nutrient reserves be limited (Bauman and Vernon, 1993).

The HR group had higher concentrations of circulating insulin before treatment throughout lactation, but this differential between the HR and LR groups diminished as lactation progressed, reflecting the likelihood that the cows entered into a positive energy balance in later lactation. Indeed, the substantial difference in BCS between the 2 groups of cows before treatment in early lactation became numerically less pronounced in later lactation. Whereas insulin is known to redirect nutrients away from the mammary gland and particularly toward adipose tissue, bST has been shown to negate this effect by decreasing the responsiveness of peripheral tissues to insulin (Rose and Obara, 1996; Rose et al., 1998). It remains to be established if the extent of this homeorhetic repartitioning caused by bST in part determines the MYR to bST.

The present experiments were designed to investigate only the short-term effects of bST, before the cows had a chance to respond with increased DMI. It is thought that the MYR of the longer-term studies are determined by the magnitude of the increase in DMI. The major factor dictating the MYR in long-term studies has apparently been the maximization of DMI (Patton and Heald, 1992; Vicini et al., 1995). It is thought that conditions that maximize DMI, such as forage quality, access to feed, and the design of the housing, are therefore critical to the long-term response to bST.

In conclusion, the present study has demonstrated that the short-term MYR to bST observed in early lactation is not different from that observed in later lactation. Poor short-term response to bST is related to indicators of negative energy balance, though it is accepted that this could also be due to other factors. Poor MYR was related to increased circulating concentrations of somatotropin and lower concentrations of IGF-I.

\section{ACKNOWLEDGMENTS}

The authors gratefully acknowledge B. Wolf (University of Wales, Aberystwyth, UK) for his help with the statistical analyses. The financial assistance of American Cyanamid Company, Princeton, $\mathrm{NJ}$, is also gratefully acknowledged.

\section{REFERENCES}

Bauman, D. E. 1992. Bovine somatotropin: Review of an emerging animal technology. J. Dairy Sci. 75:3432-3451.

Bauman, D. E. 1999. Bovine somatotropin and lactation: from basic science to commercial application. Domest. Anim. Endocrinol. 17:101-116.

Bauman, D. E., P. J. Eppard, M. J. DeGeeter, and G. M. Lanza. 1985. Responses of high-producing dairy cows to long-term treatment with pituitary somatotropin and recombinant somatotropin. J. Dairy Sci. 68:1352-1362.

Bauman, D. E., and R. G. Vernon. 1993. Effects of exogenous bovine somatotropin on lactation. Annu. Rev. Nutr. 13:437-461.

Chalupa, W., D. T. Galligan, and W. E. Marsh. 1987. Single lactational responses of cows supplemented with somatotropin daily for 266 days. Pages 34-45 in Proc. Natl. Invitational Work. Bovine Somatotropin.

East of Scotland College of Agriculture. 1976. Condition Scoring Dairy Cows. Advisory Leaflet No. 100. East of Scotland College of Agriculture, Edinburgh, UK.

Echternkamp, S. E., L. J. Spicer, K. E. Gregory, S. F. Canning, and J. M. Hammond. 1990. Concentrations of insulin-like growth factor-I in blood and ovarian follicular fluid of cattle selected for twins. Biol. Reprod. 43:8-14.

Fuller, M. F., T. E. C. Weekes, A. Cadenhead, and J. B. Bruce. 1977. The protein sparing effect of carbohydrate. 2 . The role of insulin. Br. J. Nutr. 38:489-496.

Gibson, J. P., M. Van der Meulen, B. W. McBride, and J. H. Burton. 1992. The effects of genetic and phenotypic production potential on response to recombinant bovine somatotropin. J. Dairy Sci. 75:878-884.

Hard, D. L., F. Adriaens, C. G. Prosser, J. A. Newbold, R. B. Heap, R. H. Phipps, and M. J. Hannah. 1992. Effects of recombinant bovine somatotropin (BST) and nutrition on galactopoiesis, hepatic BST receptors and plasma-hormone concentrations in the dairy-cow. J. Physiol. (Lond.) 446:P271.

Hodgkinson, S. C., J. J. Bass, and P. D. Gluckman. 1991. Plasma IGF-I binding-proteins in sheep - Effect of recombinant growthhormone treatment and nutritional-status. Domest. Anim. Endocrinol. 8:343-351.

Hof, G., P. J. Leaners, S. Tamminger, L. J. Jonker, and A. I. Kofferman. 1991. Bovine somatotropin and feed interactions in dairy cows. Livest. Prod. Sci. 28:21-36.

Johke, T. 1978. The effects of circulating growth hormone, prolactin and triiodothyronine levels in the bovine. Endocrinol. (Jpn.) 25:19-26.

Lapierre, H., J. F. Bernier, P. Dubreuil, C. K. Reynolds, C. Farmer, D. R. Ouellet, and G. E. Lobley. 1999. The effect of intake on protein metabolism across splanchnic tissues in growing beef steers. Br. J. Nutr. 81:457-466.

Lapierre, H., C. Farmer, C. Girard, and P. Brazeau. 1992. Effect of age and intake on growth hormone kinetics in dairy heifers. Domest. Anim. Endocrinol. 9:199-207.

Leitch, H. W., E. B. Burnside, and B. W. McBride. 1990. Treatment of dairy cows with recombinant bovine somatotropin: Genetic and phenotypic aspects. J. Dairy Sci. 73:181-190.

Lormore, M. J., L. D. Muller, D. R. Deaver, and L. C. Greil. 1990. Early lactation responses of dairy cows administered bovine somatotropin and fed diets high in energy and protein. J. Dairy Sci. 73:3237-3247.

Marty, B. J., and E. Block. 1992. Effects of dietary fat supplementation and recombinant bovine somatotropin on milk production, nutritional status and lipid metabolism of dairy cows. Can. J. Anim. Sci. 72:633-649.

McGuire, M. A., D. E. Bauman, D. A. Dwyer, and W. S. Cohick. 1995. Nutritional modulation of the somatotropin/insulin-like growth factor system: response to feed deprivation in lactating cows. J. Nutr. 125:493-502.

Newbold, J. A., R. B. Heap, C. G. Prosser, R. H. Phipps, F. Adriaens, and D. L. Hard. 1997. The effect of bovine somatotropin and diet on somatotropin binding sites in hepatic tissues of lactating dairy cows. J. Dairy Sci. 80:1085-1091. 
Patton, R. A., and C. W. Heald. 1992. Management of BST-supplemented cows. Page 73 in Bovine Somatotropin and Emerging Issues: An Assessment. M. C. Halberg, ed. Westview Press, Boulder, CO.

Reist, M., D. Erdin, D. von Euw, K. Tschuemperlin, H. Leuenberger, Y. Chilliard, H. M. Hammon, C. Morel, C. Philipona, Y. Zbinden, N. Kuenzi, and J. W. Blum. 2002. Estimation of energy balance at the individual and herd level using blood and milk traits in high-yielding dairy cows. J. Dairy Sci. 85:3314-3327.

Rose, M. T., F. Itoh, M. Matsumoto, Y. Takahashi, and Y. Obara. 1998. Insulin-independent glucose uptake in growth hormone treated dairy cows. J. Dairy Res. 65:423-431.
Rose, M. T., and Y. Obara. 1996. Effect of growth hormone on the response to insulin and glucose turnover in sheep. J. Agric. Sci. 126:107-115

Vicini, J. L., G. F. Hartnell, J. J. Veenhuizen, R. J. Collier, and L. Munyakazi. 1995. Effect of supplemental dietary fat or protein on the short-term milk production response to bovine somatotropin. J. Dairy Sci. 78:863-871.

Wang, Y., S. Eleswarapu, W. E. Beal, W. S. Swecker, R. M. Akers, and H. Jiang. 2003. Reduced serum insulin-like growth factor (IGF) I is associated with reduced liver IGF-I mRNA and liver growth hormone receptor mRNA in food deprived cattle. J. Nutr. $133: 2555-2560$ 